Pesq. Vet. Bras. 36(8):767-774, agosto 2016 DOI: $10.1590 /$ S0100-736X2016000800015

\title{
Identification of ultrastructural and functional damages in sperm from six-banded armadillos (Euphractus sexcinctus) due to cryopreservation ${ }^{1}$
}

\author{
Patrícia C. Sousa², Erika A.A. Santos², Andréia M. Silva², José A.B. Bezerra², Ana L.P. \\ Souza $^{2}$, Gabriela L. Lima ${ }^{3}$, Moacir F. Oliveira ${ }^{2}$ and Alexandre R. Silva ${ }^{2 *}$
}

\begin{abstract}
Sousa P.C., Santos E.A.A., Silva A.M., Bezerra J.A.B., Souza A.L.P., Lima G.L., Oliveira M.F. \& Silva A.R. 2016. Identification of ultrastructural and functional damages in sperm from six-banded armadillos (Euphractus sexcinctus) due to cryopreservation. Pesquisa Veterinária Brasileira 36(8):767-774. Laboratory of Animal Germoplasm Conservation, Universidade Federal Rural do Semi-Árido, BR-110 Km 47, Presidente Costa e Silva, Mossoró, RN 599625-900, Brazil. E-mail: legio2000@yahoo.com

The aim of the study was to cryopreserve the semen of six-banded armadillos (Euphractus sexcinctus) in Tris-yolk and glycerol diluent, and to determine the damage caused by the freezing-thawing process, using fluorescent markers and ultrastructural analysis. Semen samples $(\mathrm{n}=11)$ collected from 4 adult six-banded armadillos by electroejaculation were cryopreserved in Tris diluent plus 20\% egg yolk and 3\% glycerol, in a fast freezing curve. Classical analysis of samples was performed after dilution, refrigeration and thawing, followed by fluorescence analysis, using a combination of fluorescent probes to assess membrane integrity (propidium iodide - PI and Hoechst - H342), and mitochondrial activity (CMXRos - Mito Tracker Red ${ }^{\circledR}$ ). We also used the ultrastructural analysis to verify possible morphological alterations caused by cryoinjuries. When compared with fresh samples, we verified a significant decline in all the armadillos' semen parameters after thawing, in which only $6.1 \%$ motile sperm were found. However, the percentage of sperm which remained with viable (13\%) and functional (24.7\%) membranes after thawing suggests that some cells could be live but immotile. Analysis using fluorescent markers revealed that the mitochondria of armadillos' sperm is highly sensible to the freezing protocol and the findings through ultrastructure analysis proved this statement. Additionally, the images obtained by transmission electron microscopy revealed that frozen-thawed sperm presented damaged plasma membrane, nuclear modifications as changes in chromatin and acrossomal changes relative to sperm capacitation. In conclusion, this study is the first attempt to cryopreserve the semen of an armadillo species, and to help us to identify critical points on the freezing-thawing procedure in order to improve the protocol.
\end{abstract}

INDEX TERMS: Ultrastructural and functional damages, sperm, six-banded armadillo, Euphractus sexcinctus, cryopreservation, Xenarthras, semen, membrane integrity, mitochondrial activity, ultrastructure.

RESUMO.- [Identificação de danos ultraestruturais e funcionais em espermatozoides de tatus-peba (Euphractus sexcinctus) oriundos da criopreservação.] 0

\footnotetext{
${ }^{1}$ Received on February 2, 2016.

Accepted for publication on May 13, 2016.

${ }^{2}$ Laboratory of Animal Germoplasm Conservation, Universidade Federal Rural do Semi-Árido (UFERSA), BR-110 Km 47, Presidente Costa e Silva, Mossoró, RN 599625-900, Brazil. *Corresponding author: legio2000@ yahoo.com

${ }^{3}$ Centro de Ciências Agrárias, Universidade Federal de Roraima (UFRR), Campus Murupu, Rodovia BR-174 Km 37, Sede da antiga Fazenda Bamerindus s/n, PA Nova Amazônia, Boa Vista, RR 69300-000, Brazil.
}

objetivo deste estudo foi criopreservar o sêmen de tatus-peba (Euphractus sexcinctus) em diluente Tris-gema e glicerol, e determinar os danos causados pelo processo de congelação-descongelação, utilizando marcadores fluorescentes e análise ultraestrutural. As amostras de sêmen $(n=11)$ coletadas de 4 tatus-peba adultos por eletroejaculação foram criopreservadas em diluente Tris acrescido de $20 \%$ de gema de ovo e $3 \%$ de glicerol, em curva rápida de congelação. A análise clássica das amostras foi realizada após a diluição, refrigeração e descongelação, seguida por análise de fluorescência, utilizando uma combinação de sondas flu- 
orescentes para avaliar a integridade da membrana (Iodeto de Propídio - PI e Hoechst - H342), e a atividade mitocondrial (CMXRos - Mito Tracker RED ${ }^{\circledR}$ ). Foi também utilizada a análise ultraestrutural para verificar possíveis alterações morfológicas causadas pela crioinjúria. Quando comparadas com as amostras a fresco, verificou-se uma queda significativa em todos os parâmetros seminais dos tatus após a descongelação, em que apenas $6,1 \%$ de espermatozoides móveis foram encontrados. No entanto, o percentual de espermatozoides que permaneceu com membrana viável (13\%) e funcional $(24,7 \%)$ após a descongelação sugere que algumas células podem estar vivas, mas imóveis. Análises utilizando marcadores fluorescentes revelaram que as mitocôndrias dos espermatozoides de tatus são altamente sensíveis ao protocolo de congelação e os achados através da análise ultraestrutural comprovaram esta afirmação. Além disso, as imagens obtidas por microscopia eletrônica de transmissão revelaram que espermatozoides congelados-descongelados apresentaram membranas plasmáticas danificadas, modificações nucleares como alterações na cromatina, e alterações acrossomais relativas à capacitação espermática. Em conclusão, este estudo é a primeira tentativa de criopreservação de sêmen em uma espécie de tatu, e nos auxiliou a identificar pontos críticos no processo de congelação-descongelação, a fim de melhorar o protocolo.

TERMOS DE INDEXAÇÃO: Danos ultraestruturais e funcionais, espermatozoides, tatu-peba, Euphractus sexcinctus, criopreservação, Xenartra, sêmen, membrana, mitocondria, ultraestrutura.

\section{INTRODUCTION}

From the 38 species of mammals belonging to the Xenarthra order, at least nine are vulnerable or endangered, such as armadillos from the genus Tolypeutes and the giant armadillo (Priodontes maximus) (IUCN 2016). However, the six-banded armadillo (E. sexcinctus), a Dasipodidae family member, has been classified as a species of stable and not threatened population (IUCN 2016), and can be used as an ideal experimental model to develop reproductive biotechnologies for other threatened species of the same group. However, studies related to physiology and biotechnology of reproduction in armadillos and other species of Xenartra order are scarce and limited to the characterization and the classical analysis of in natura semen (Heath et al. 1987, Peres et al. 2008, Serafim et al. 2010, Santos et al. 2011, Luba et al. 2015).

Semen cryopreservation appears as a strategy of great importance for breeding and maintenance of genetic diversity in wildlife, and provides a long-term genetic pool for animal germplasm banks, currently an important part in many wildlife conservation programs (Pukazhenthi et al. 2006). This process starts from the preservation of sperm in extenders containing buffer system, energy substrate, phospholipids and cryoprotectants in appropriate concentrations to maintain the quality and the fertilizing capacity of these cells for long periods (Hoe et al. 2001). Meantime, cryopreservation can cause serious damage to sperm because of the influence of several factors, such as brusque temperature changes, the occurrence of osmotic stress, the toxicity due to exposure to cryoprotectants and the forma- tion of intra and extracellular ice crystals (Medeiros et al. 2002).

To determine and identify such cryoinjuries, different sperm assessment techniques are used. Conventionally, the sperm motility and morphologic analysis are used as quick tests for semen samples. However, they do not show alterations when the morphological defects are expressed in a nanometer scale (Crespilho et al. 2006), which are revealed by electron microscopy. Even with the advances of this technique, there is little data regarding the damage induced by the cryopreservation in sperm ultrastructure, and most of them are directed to domestic animals (Silva et al. 2009). With regard to wildlife, these studies are even more rare (Sa-Ardrit et al. 2006).

Although damage on the sperm morphology is most apparent during semen cryopreservation, the physical stress on sperm membranes is seen as a major limiting factor (Pesch \& Bergman 2006). Based on this aspect, great emphasis has been given to the use of fluorescent markers that show specific cellular structures and clearly detect the structural and functional integrity of sperm (Celeghini et al. 2007).

Given the importance of semen cryopreservation for the conservation of wild species, this work represents a first step towards implementing a germplasm bank facing the preservation of genetic material from Xenarthras. Thus, our aim was to cryopreserve, for the first time, the semen of six-banded armadillos (E. sexcinctus) in tris-yolk and glycerol-based diluent, and determine the main cryoinjuries caused by this process using fluorescent markers and ultrastructural analysis.

\section{MATERIALS AND METHODS}

All experimental protocols and animal care procedures were approved by the Ethics Committee of the Federal University of the Semi-arid (UFERSA) (Process $\left.n^{\circ} .23091 .002754 / 2011-99\right)$. All reagents were obtained from Sigma-Aldrich, Co, St Louis, MO, USA, except when mentioned.

Animals. Four mature, male six-banded armadillos were used for the study. The animals weighed $3.25 \pm 0.2 \mathrm{~kg}$ and were sexually mature, aging about 1.5 years old. They were previously captured from their natural habitat and kept in captivity for 1 year before the start of the experiment. They were housed in individual cages used in the Center for Multiplication of Wild Animals (CEMAS/ UFERSA), located in the northeast of Brazil (Mossoró, RN, Brazil; $5^{\circ} 10^{\prime} \mathrm{S}$ and $37^{\circ} 10^{\prime} \mathrm{W}$; temperature range, $27-29^{\circ} \mathrm{C}$ ), under $11 \mathrm{~h}$ of natural photoperiod conditions. They were fed dog chow pellets and fruits once daily, with ad libitum access to water.

Semen collection. For semen collection, each armadillo was submitted to three sessions of electroejaculation on a 15-30 days interval. The animals were mechanically restrained with the aid of suitable gloves. A pre-anesthetic medication was administered using xylazine $1 \mathrm{mg} / \mathrm{kg}\left(\operatorname{Sedomin}^{\circledR}\right.$, König SA, Buenos Aires, Argentina) and ketamine $7 \mathrm{mg} / \mathrm{kg}$ (Ketamine Injection ${ }^{\circledR}$, Vetnil, Sao Paulo, Brazil) intramuscularly, then the maintenance of anesthetic plan was achieved via the intravenous administration of propofol $5 \mathrm{mg} / \mathrm{kg}$ (Propovan ${ }^{\circledR}$, Cristalia, Fortaleza, Brazil) (Amorim et al. 2011). The animals were placed in dorsal recumbency, and their pubic region cleaned. The same electroejaculation procedure was used for all animals and lasted approximately $15 \mathrm{~min}$. An electroejaculator (Eletrojet ${ }^{\circledR}$, Eletrovet, São Paulo, SP, Brazil) connected to a $12 \mathrm{~V}$ source, was used to deliver three stimulation cycles, having 
5 min interval between successive cycles. The first cycle consisted of 10 stimuli of 2,3 , and $4 \mathrm{~mA}$, in succession; the second was 10 stimuli of 3, 4 and $5 \mathrm{~mA}$, sequentially; and the third was 10 stimuli of 5 and $6 \mathrm{~mA}$ (Serafim et al. 2010). The electroejaculator probe measured $12.5 \mathrm{~cm}$ (length) and $1.0 \mathrm{~cm}$ (diameter) and contained two longitudinal electrodes. About $8 \mathrm{~cm}$ of the probe was inserted into the rectum of each armadillo. Semen was collected in plastic tubes and immediately evaluated.

Semen evaluation. The semen color and aspect were noted. Micropipettes varyng from 5 to $200 \mu \mathrm{L}$ were used to measure the semen volume. Sperm motility (percentage of total motile sperm; evaluated in increments of 5\%) and vigor (strength of the sperm flagellum beating; 0-5 scale) were assessed immediately, using light microscopy (Eclipse E200, Nikon, Melville, NY, USA) under $100 \times$ and $400 \times$ magnification. Eosin-nigrosin stained smears were prepared with $5 \mu \mathrm{L}$ of semen (1:1) to evaluate the sperm viability. To determine sperm concentration, an aliquot of $10 \mu \mathrm{L}$ of semen was diluted in formolized solution $(10 \%)$ buffered $(1 \mathrm{~mL})$ and observed in a Neubauer chamber. Sperm's functional integrity was analyzed by the hypoosmotic swelling test, using an aliquot of $5 \mu \mathrm{L}$ of semen in $45 \mathrm{uL}$ of distilled water $(50 \mathrm{mOsm} / \mathrm{L})$ as the hypo-osmotic solution, then 200 cells were counted (Santos et al. 2011).

Cryopreservation of semen. Each sample of fresh semen was diluted with Tris [Tris-hydroxymethyl aminometane, 3.028g, citric acid monohydrate 1.78g and D-fructose 1.25g], plus 20\% egg yolk (Sousa et al. 2014). Samples were cooled for $40 \mathrm{~min}$ in a $5 \mathrm{~L}$ isothermic box (Isoplast ${ }^{\circledR}$, Fortaleza, CE, Brazil), at $15^{\circ} \mathrm{C}$, and further transferred to an incubator (Quimis ${ }^{\circledR}$, Diadema, SP, Brazil) for 30 min to reach $4^{\circ} \mathrm{C}$, being evaluated at this moment. Then, samples were added to Tris-egg yolk plus 6\% glycerol, resulting in a final concentration of $3 \%$ glycerol in extender. Final diluition resulted in a sperm concentration of $150 \times 10^{6} \mathrm{sperm} / \mathrm{ml}$. Samples from the same animal were packed into $0.25 \mathrm{~mL}$ plastic straws (IMV - Technologies ${ }^{\circledR}$, L' Aigle France), which were frozen in nitrogen $\left(\mathrm{N}_{2}\right)$ for storage (Silva et al. 2011). After 1 week, the straws of each animal were thawed on a water bath, at $37^{\circ} \mathrm{C}$ for $1 \mathrm{~min}$ and re-evaluated.

Analysis by fluorescent probes. Immediately after dilution and thawing, a semen aliquot $(10 \mu \mathrm{L})$ was incubated at $34^{\circ} \mathrm{C}$ for $10 \mathrm{~min}$ in a solution composed of the following combination of fluorescent probes: $2 \mu \mathrm{L}$ Propidium Iodide (PI); $0.5 \mathrm{mg} / \mathrm{ml} \mathrm{NaCl}$ at $0.9 \%$; $5 \mu \mathrm{L}$; CMXRos (Mito Tracker Red $\AA$, Molecular Probes, F-7512) at $500 \mathrm{nM}$ (dilution of $50 \mu \mathrm{g}$ in $94 \mu \mathrm{L}$ of DPBS); and $3 \mu \mathrm{L}$ Hoechst 342 (H342) (diluted at 25mg/mL in DMSO), according to the methodology described by Celeghini et al. (2007). Next, the samples were evaluated with an epifluorescence microscope (Episcopic Fluorescent Attachment "EFA" Halogen Lamp Set, Leica, Kista, Sweden), and 200 spermatozoa (per sample) were evaluated for the plasma membrane integrity using PI/H342 association and for mitochondrial membrane potential through CMXRos. Sperm heads marked in blue (H342) were considered to have intact membrane and those totally or partially marked with red (PI) were considered to be not intact; region of the midpiece marked in red was considered as presenting mitochondrial activity (Celeghini et al. 2007).

Morphological analysis. The sperm morphological analysis was conducted on semen smears stained with Bengal Rose, and
200 cells/slide were observed through light microscopy under magnification of $1000 \times$ (Sousa et al. 2013). For ultrastructural analysis, two pools comprised of a semen sample from each animal were used; one of the pools was of fresh samples and the other, thawed. Each pool was centrifuged at $800 \mathrm{~g}$ for $10 \mathrm{~min}$. Pellets were fixed using a slightly modified Karnovsky (1965) solution, containing paraformaldehyde $2 \%$ and glutaraldehyde $2 \%$ in phosphate buffer $0.1 \mathrm{M}$ pH 7.4 (PB-Sigma $\mathrm{Co}^{\circledR}$, St Louis, United States) and held at $4^{\circ} \mathrm{C}$. Fixed samples were washed in phosphate buffer, then post-fixed with osmium tetroxide $1 \%$, dehydrated in propylene oxide, and embedded in eponresin (Embed 812, Electron Microscopy Sciences, Hatfield, United States). Ultra fine sections (60-70nm) were manually stained with uranyl acetate and lead citrate. Random fields were examined by a transmission electronic microscope (JEOL 1010, Japan) and photographed for further analysis and description.

Statistical analysis. The results were expressed as Mean \pm Standard Error (SE) and analyzed using the StatView ${ }^{\circledR} 5.0$ software for Windows (SAS Institute Inc., Cary, USA). Data were checked for homoscedasticity through Levene's test. Then the data were subjected to angular transformation in arcsine, except for data concerning sperm vigor. The effect of the individual and the cryopreservation on semen parameters was checked at using the Fisher PLSD test $(\mathrm{P}<0.05)$; except on the vigor that was verified by the Mann-Whitney test $(\mathrm{P}<0.05)$.

\section{RESULTS}

Each armadillo ejaculated three times, except one that failed in one occasion. On a total, eleven ejaculates were obtained and used for the experiment. The six-banded armadillos' ejaculates showed white color with translucent appearance, alkaline $\mathrm{pH}$, always with value close to 9 , and high viscosity. The ejaculates presented $410 \pm 86.5 \mathrm{~mL}$ with a concentration of $139.58 \pm 33 \times 10^{6} \mathrm{sperm} / \mathrm{mL}$. We observed a marked individual variation among animals in terms of their fresh semen characteristics (Table 1). In such analysis, we often observed sperm aggregated head-head (rouleaux formation), which persited even after dilution.

The chilling procedure provoked a significant reduction on the percentage of motile sperm, which intensified after thawing $(\mathrm{P}<0.05)$. However, the sperm vigor, vability and osmotic response were only negatively affected $(\mathrm{P}<0.05)$ after thawing (Table 2). In addition, the analysis through fluorescent probes (Table 3 ) revealed the damage to plasma membrane and mitochondrias caused by cryopreservation and the thawing procedure, when compared with values found for dluted semen $(\mathrm{P}<0.05)$. The response of sperm from six-banded armadillos submitted to an association of fluorescent markers can be seen in Figure 1.

Regarding the morphological analysis of sperm under light microscopy (Table 4), there was a decrease in the percentage of normal cells from the fresh semen to the colled and thawing samples $(\mathrm{P}<0.05)$. Through ultrastructural

Table 1. Mean ( \pm SE) values for seminal parameters of fresh semen (in natura) from six-banded armadillos (E. sexcinctus) ( $n=11$ ejaculates)

\begin{tabular}{|c|c|c|c|c|c|}
\hline Semen Parameters & $\begin{array}{c}\text { Animal } 1 \\
(\mathrm{n}=3)\end{array}$ & $\begin{array}{c}\text { Animal } 2 \\
(\mathrm{n}=3)\end{array}$ & $\begin{array}{c}\text { Animal } 3 \\
(\mathrm{n}=3)\end{array}$ & $\begin{array}{c}\text { Animal } 4 \\
(\mathrm{n}=2)\end{array}$ & Overall \\
\hline Concentration $(\mathrm{x} 106$ sperm $/ \mathrm{mL})$ & $58.3 \pm 24.5^{\mathrm{a}}$ & $160 \pm 36^{\mathrm{b}}$ & $173.3 \pm 86.5^{\mathrm{ab}}$ & $166,6 \pm 100.8^{\mathrm{ab}}$ & $139.58 \pm 33^{b}$ \\
\hline Volume $(\mu \mathrm{L})$ & $183 \pm 72.6^{\mathrm{ac}}$ & $775 \pm 225^{b}$ & $333 \pm 120.2^{\text {cd }}$ & $500 \pm 204.3^{\text {bd }}$ & $410 \pm 86.5^{\mathrm{d}}$ \\
\hline
\end{tabular}


Table 2. Mean ( \pm SE) values for seminal parameters of six-banded armadillos (A) sperm during different steps of cryopreservation

\begin{tabular}{|c|c|c|c|c|c|c|}
\hline \multirow[t]{2}{*}{ Semen Parameters } & \multirow[t]{2}{*}{ Step } & \multicolumn{5}{|c|}{ Individuals } \\
\hline & & A 1 & A 2 & A 3 & A 4 & Overall \\
\hline \multirow[t]{3}{*}{ Motility (\%) } & Fresh & $91.6 \pm 1.6^{\mathrm{Aa}}$ & $86.6 \pm 3.3^{\mathrm{Aab}}$ & $81.6 \pm 10.4^{\mathrm{Aab}}$ & $75.5 \pm 5^{\mathrm{Ab}}$ & $84.5 \pm 2.5^{\text {Aab }}$ \\
\hline & Cooled & $43.3 \pm 14.5^{\text {Bab }}$ & $48.3 \pm 19.6^{\mathrm{ABab}}$ & $33.3 \pm 6.6^{\mathrm{Ba}}$ & $81 \pm 5^{\mathrm{Ab}}$ & $49.5 \pm 8.2^{\mathrm{Ba}}$ \\
\hline & Frozen/thawed & $2 \pm 1.2^{\mathrm{Ca}}$ & $10 \pm 10^{\mathrm{Bab}}$ & $11.6 \pm 6^{\mathrm{Cb}}$ & $1 \pm 1^{\mathrm{Ba}}$ & $6.6 \pm 3.1^{\mathrm{Ba}}$ \\
\hline \multirow[t]{3}{*}{ Vigor (0-5) } & Fresh & $1.6 \pm 0.3^{\mathrm{Aa}}$ & $1.6 \pm 0.3^{\mathrm{Aa}}$ & $1 \pm 0^{\mathrm{Aa}}$ & $1 \pm 0^{\mathrm{Aa}}$ & $1.3 \pm 0.14^{\mathrm{Aa}}$ \\
\hline & Cooled & $1 \pm 0^{\mathrm{Aa}}$ & $1.3 \pm 0.3^{\mathrm{Aa}}$ & $1.3 \pm 0.3^{\mathrm{Aa}}$ & $2 \pm 1^{\mathrm{Aa}}$ & $1.3 \pm 0.2^{\mathrm{Aa}}$ \\
\hline & Frozen/thawed & $0.6 \pm 0.3^{\mathrm{Ba}}$ & $0.3 \pm 0.3^{\mathrm{Ba}}$ & $0.6 \pm 0.3^{\mathrm{Ba}}$ & $0.3 \pm 0.3^{\mathrm{Ba}}$ & $0.5 \pm 0.2^{\mathrm{Ba}}$ \\
\hline \multirow[t]{3}{*}{ Viability (\%) } & Fresh & $58.3 \pm 5.2^{\mathrm{Aa}}$ & $52.6 \pm 4.1^{\mathrm{Aa}}$ & $66.3 \pm 3.2^{\mathrm{Aa}}$ & $76.5 \pm 10.5^{\mathrm{Aa}}$ & $61.5 \pm 3.2^{\mathrm{Aa}}$ \\
\hline & Cooled & $57 \pm 14.9^{\text {Аа }}$ & $51.6 \pm 11,8^{\mathrm{Aa}}$ & $37.3 \pm 14.8^{\mathrm{ABa}}$ & $82.5 \pm 9.5^{\mathrm{Aa}}$ & $54.8 \pm 8.2^{\mathrm{Aa}}$ \\
\hline & Frozen/thawed & $5.6 \pm 1.3^{\mathrm{Ba}}$ & $29 \pm 18.5^{\text {Аа }}$ & $9.6 \pm 1.7^{\mathrm{Ba}}$ & $5.5 \pm 3.5^{\mathrm{Ba}}$ & $13.1 \pm 5.4^{\mathrm{Ba}}$ \\
\hline \multirow{3}{*}{ Osmotic response (\%) } & Fresh & $64.5 \pm 6.5^{\text {Аа }}$ & $86 \pm 4.2^{\mathrm{Aa}}$ & $50.3 \pm 10.7^{\mathrm{Aa}}$ & $74.5 \pm 10.5^{\text {Аа }}$ & $64.37 \pm 6.4^{\mathrm{Aa}}$ \\
\hline & Cooled & $34.3 \pm 8.2^{\mathrm{Ba}}$ & $39 \pm 2^{\mathrm{Ba}}$ & $45.6 \pm 6.4 \mathrm{~A}^{\mathrm{Ba}}$ & $52 \pm 10^{\mathrm{Aa}}$ & $42.2 \pm 3.8 A^{\mathrm{Ba}}$ \\
\hline & Frozen/thawed & $26.3 \pm 6.3^{\mathrm{Ba}}$ & $41.3 \pm 12.4^{\text {Ва }}$ & $21 \pm 9.5^{\mathrm{Ba}}$ & $10.3 \pm 5.8^{\mathrm{Ba}}$ & $24.7 \pm 8.6^{\mathrm{Ba}}$ \\
\hline
\end{tabular}

$\overline{\mathrm{ABC}}$ Among lines, different superscript capital letters indicate significant differences among fresh, cooled and post-thawing samples for each individual and the overall values $(\mathrm{P}<0.05)$;

abc Among columns, for the same parameter within the same treatment. Means without a common superscript letter differed between themselves $(\mathrm{P}<0.05)$.

Table 3. Mean $( \pm S E)$ values for integrity of the membranes and mitochondrial function identified through fluorescence analysis in six-banded armadillo (A) (E. sexcinctus) sperm after dilution and thawing

\begin{tabular}{|c|c|c|c|c|c|c|}
\hline \multirow[t]{2}{*}{ Semen parameters } & \multirow[t]{2}{*}{ Step } & \multicolumn{5}{|c|}{ Individuals } \\
\hline & & A1 & A2 & A3 & A4 & Overall \\
\hline Membrane integrity and & Diluted & $32.5 \pm 1.5^{\text {Аа }}$ & $32.3 \pm 3.5^{\mathrm{Aa}}$ & $29.3 \pm 4.4^{\mathrm{Aa}}$ & $28 \pm 9^{\mathrm{Aa}}$ & $30.6 \pm 2^{\mathrm{Aa}}$ \\
\hline active mitochondria (\%) & Frozen/thawed & $0^{\mathrm{Ba}}$ & OBa & $4.6 \pm 2.6^{\mathrm{Bb}}$ & $2.5 \pm 2.5^{\mathrm{Bb}}$ & $1.9 \pm 1^{\mathrm{Bb}}$ \\
\hline Membrane integrity and & Diluted & $1.5 \pm 1.5^{\mathrm{Aa}}$ & $1.0 \pm 1^{\text {Аа }}$ & $1.0 \pm 0.6^{\mathrm{Aa}}$ & $1.5 \pm 1.5^{\mathrm{Aa}}$ & $1.2 \pm 0.4^{\mathrm{Aa}}$ \\
\hline unable mitochondria (\%) & Frozen/thawed & $10 \pm 4^{\mathrm{Ba}}$ & $6.6 \pm 5.2^{\mathrm{Ba}}$ & $2.6 \pm 1.4^{\mathrm{Aa}}$ & $4.5 \pm 3^{\mathrm{Aab}}$ & $5.7 \pm 1.8^{\mathrm{Ba}}$ \\
\hline Membrane not functional & Diluted & 0 & 0 & 0 & 0 & 0 \\
\hline and active mitochondria (\%) & Frozen/thawed & 0 & 0 & 0 & 0 & 0 \\
\hline Membrane not functional & Diluted & $66 \pm 3^{\mathrm{Aa}}$ & $66.3 \pm 4.3^{\mathrm{Aa}}$ & $71.6 \pm 2.6^{\mathrm{Aa}}$ & $70.5 \pm 7.5^{\mathrm{Aa}}$ & $68.8 \pm 1.9^{\mathrm{Aa}}$ \\
\hline and unable mitochondria (\%) & Frozen/thawed & $90 \pm 4^{\mathrm{Ba}}$ & $93.3 \pm 5.2^{\mathrm{Ba}}$ & $91.6 \pm 1.2^{\mathrm{Ba}}$ & $95.3 \pm 2.6^{\mathrm{Aa}}$ & $92.1 \pm 1.6^{\mathrm{Ba}}$ \\
\hline
\end{tabular}

$\overline{{ }^{A B C}}$ Among lines, different superscript capital letters indicate significant differences among fresh, cooled and post-thawing samples for each individual and the overall values $(\mathrm{P}<0.05)$;

${ }^{a b c}$ Among columns, for the same parameter within the same treatment. Means without a common superscript letter differed between themselves $(\mathrm{P}<0.05)$.

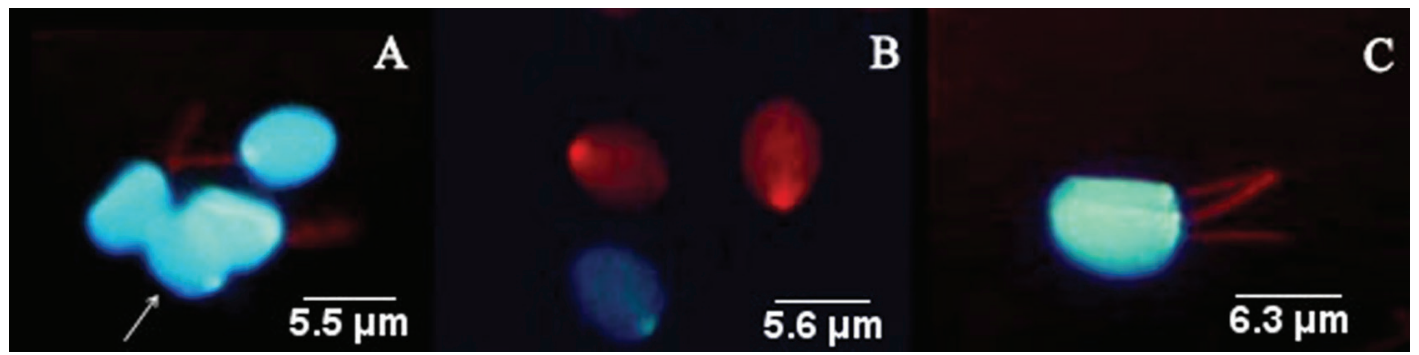

Fig.1. Plasma membrane integrity and mitochondrial activity of cryopreserved sperm from six-banded armadillos (Euphractus sexcinctus) assessed by the association of fluorescent H3342/IP/Mito Traker Red ${ }^{\circledR}$ markers. (A) Sperm marked in blue with Hoechst 3342 fluorophore (H-342) and fluorescent midpiece in red, stained with Mito Traker Red ${ }^{\circledR}$ indicate, respectively, plasma membrane integrity and presence of mitochondrial activity. The arrow indicates sperm with intact plasma membrane, but without mitochondrial activity. (B) Sperm marked in red with propidium iodide (PI), indicating membrane damage and marked in blue with H-342, indicating membrane integrity, but does not exhibit midpiece by fluorescent red Mito Traker Red ${ }^{\circledR}$, indicating absence of mitochondrial activity. (C) Sperm in "rouleaux", with intact plasma membrane and mitochondrial activity. 400x.

analysis (Fig.2 and 3), it was found that fresh sperm plasma membranes presented a slightly wavy aspect, with acrosomal membranes well preserved and defined (Fig.2A). In the region of the midpiece, we observed well preserved mitochondrial sheaths and juxtaposed mitochondria, with internal ridges immersed in a dense and uniform matrix (Fig.3A,C). In contrast, the spermatozoa subjected to cryo- preservation exhibited ultrastructural changes characterized by abnormal appearance of the head (Fig.2E), distension and rupture of the plasma membrane (Fig.2D) (Fig.3E), presence of vesicular formations in the region adjacent to the inner acrosomal membrane (Fig.2B E) and enabled acrosome (Fig.2C). In addtion, cryopreserved samples presented altered midpieces, characterized by abnormal 
Table 4. Mean $( \pm \mathrm{SE})$ values for the morphological analysis of sperm from six-banded armadillo (E. sexcinctus) at different steps of cryopreservation

\begin{tabular}{lccc}
\hline Sperm characteristics (\%) & Fresh & Cooled & Post-thawed \\
\cline { 2 - 4 } Normal sperm & $78 \pm 2.8^{\mathrm{a}}$ & $69.4 \pm 2.5^{\mathrm{b}}$ & $53.1 \pm 3.8^{\mathrm{c}}$ \\
\hline Tail defect & & & \\
$\quad$ Coiled tail & $6.8 \pm 1^{\mathrm{a}}$ & $9.4 \pm 0.9^{\mathrm{ac}}$ & $12.4 \pm 1.1^{\mathrm{c}}$ \\
Bent coiled tail & $5 \pm 1.0^{\mathrm{ab}}$ & $6.4 \pm 0.8^{\mathrm{b}}$ & $8.2 \pm 0.8^{\mathrm{b}}$ \\
$\quad$ Broken tail & $1.4 \pm 0.3^{\mathrm{a}}$ & $1.2 \pm 0.4^{\mathrm{a}}$ & $4.2 \pm 1.6^{\mathrm{b}}$ \\
$\quad$ Other tail defects & $1.3 \pm 0.3^{\mathrm{a}}$ & $1.5 \pm 0.5^{\mathrm{a}}$ & $1.6 \pm 0.8^{\mathrm{a}}$ \\
Midpiece & & & \\
$\quad$ Reflex midpiece & $1.9 \pm 0.4^{\mathrm{a}}$ & $3.8 \pm 1.0^{\mathrm{a}}$ & $2.9 \pm 0.9^{\mathrm{a}}$ \\
Broken midpiece & $0.3 \pm 0.2^{\mathrm{a}}$ & $1.3 \pm 0.7^{\mathrm{a}}$ & $2.4 \pm 1.2^{\mathrm{a}}$ \\
$\quad$ Thick midpiece & $0^{\mathrm{a}}$ & $0.1 \pm 0.1^{\mathrm{a}}$ & $0^{\mathrm{a}}$ \\
Head defect & & & \\
$\quad$ Macrocephaly & $0.1 \pm 0.1^{\mathrm{a}}$ & $0^{\mathrm{a}}$ & $0^{\mathrm{a}}$ \\
Microcephaly & $0.5 \pm 0.3^{\mathrm{a}}$ & $0.3 \pm 0.1^{\mathrm{a}}$ & $0.3 \pm 0.1^{\mathrm{a}}$ \\
Abnormal head & $1.6 \pm 0.4^{\mathrm{a}}$ & $1.5 \pm 0.5^{\mathrm{a}}$ & $4.4 \pm 1.1^{\mathrm{b}}$ \\
Detached head & $2.4 \pm 0.9^{\mathrm{a}}$ & $3.4 \pm 0.9^{\mathrm{a}}$ & $6.9 \pm 2.4^{\mathrm{a}}$ \\
a,b,c Among columns, means without a common superscript letter differed \\
between themselves $(\mathrm{P}<0.05)$.
\end{tabular}

mitochondria, with amorphous aspect, disorganized mitochondrial ridges, and heterogeneous matrix (Fig.3B,D,E). However, it should be noted that despite the higher incidence of damage in frozen-thawed sperm, we also observed some preserved sperm in cryopreserved samples.

\section{DISCUSSION}

To facilitate the application of biotechniques for the conservation of gametes, protocols employed in individuals of the same taxon can be used as reference, because these animals show similar morphological, genetic and ecological characteristics (Hickman Jr. et al. 2004). On a recent study developed by our team, we demonstrated that a Tris extender is more effective in maintaining armadillo's sperm viability for $120 \mathrm{~min}$ at $34^{\circ} \mathrm{C}$ than a coconut water extender (Sousa et al. 2014). For this reason, we chose the Tris as the diluting medium for this first attempt on armadillos' sperm freezing. However, due to the absence of any information related to the use of sperm cryopreservative techniques for any Xenartra species in current scientific literature, we decided for using a protocol previously stablished for other wild mammals, such as the agoutis (Dasyprocta aguti) (Silva et al. 2011). Moreover, nothing was known about the relationship between morphofunctional sperm parameters and fertilization ability in six-banded armadillos. The majority of studies that tests the application of reproductive biotechniques in mammals usually highlights the sperm motility and membrane integrity as the main parameters to assess sperm freezing techniques (Silva et al. 2009), reason why we focused the present study in analyzing these parameter.

In the present study, a decline in the quality of armadillo's frozen-thawed samples was evident, with sperm motility decreasing from $79 \%$ in fresh samples to values close to $49 \%$ and $10 \%$ after chilling and thawing, respectively. Similarly, Amorim et al. (2012) had previously demonstrated that six-banded armadillo's sperm is very sensible to low emperatures, even if diluted in Tris or $\mathrm{ACP}^{\circledR}$ extenders for storage at $5^{\circ} \mathrm{C}$. In a recent study, Luba et al. (2015) also verified a rapid decline in the quality of giant anteater sperm after dilution in a commercial extender (Botucrio ${ }^{\circledR}$, Botupharma Ltda, Botucatu, SP, Brazil) under

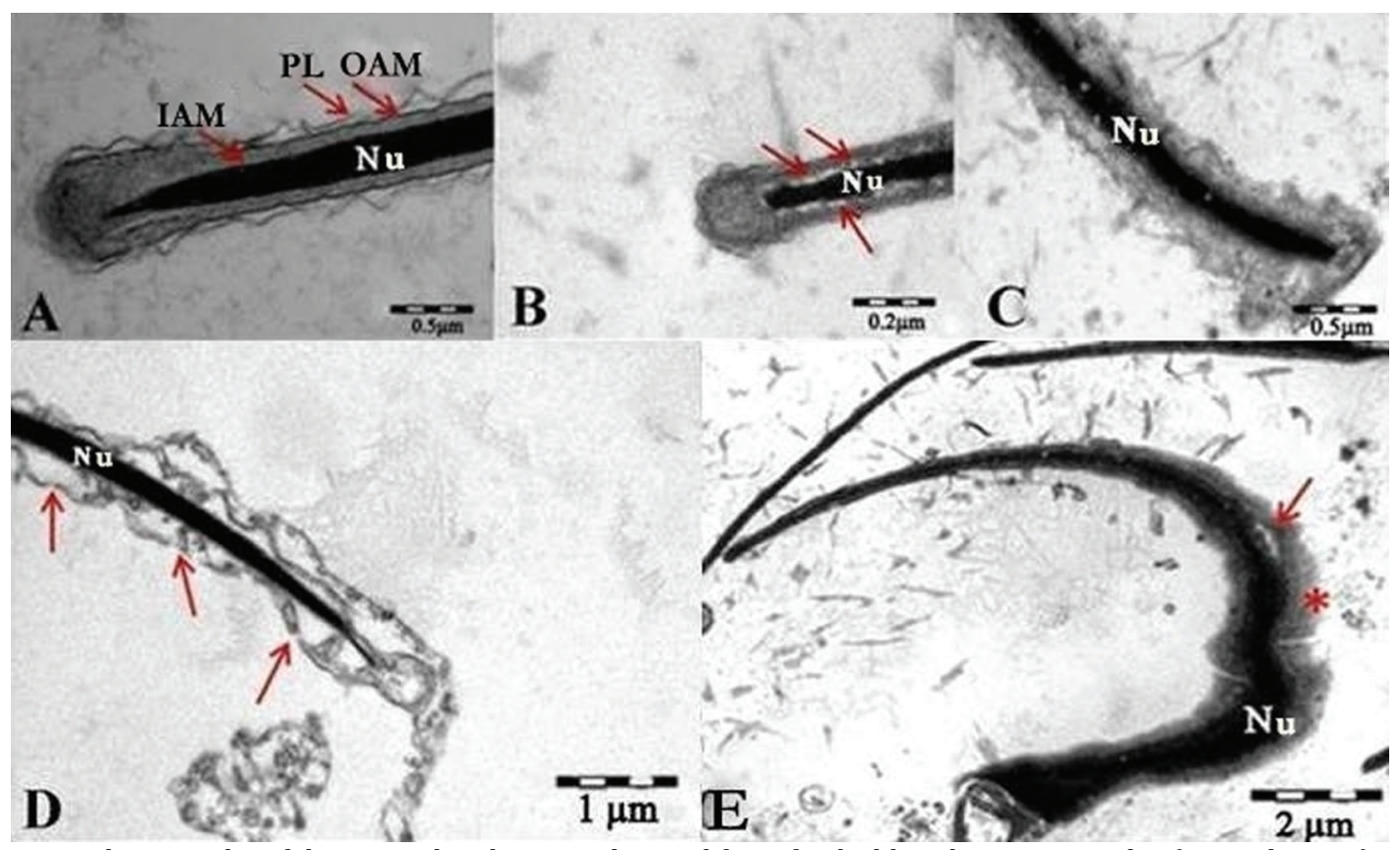

Fig.2. Electron microphotography of the sperm head region obtained from fresh-diluted semen samples (control group) and frozen-thawed samples from six-banded armadillos (Euphractus sexcinctus). (A) Normal sperm (control group) with slightly ondulating plasma membranes, and well defined limits between the nucleus and the acrosome. (B) Sperm presenting electrolucent points between the nucleus $(\mathrm{Nu})$ and inner acrosomal membrane (red arrows). (C) Undefined acrosome membrane, indicating sperm capacitation. (D) Longitudinal section of cryopreserved sperm showing disruption and vacuolization of the plasma membrane; (E) deformation of the sperm head (falciform), with apparent nuclear damage (arrow) adjacent to qualified acrosome (capacitation). 


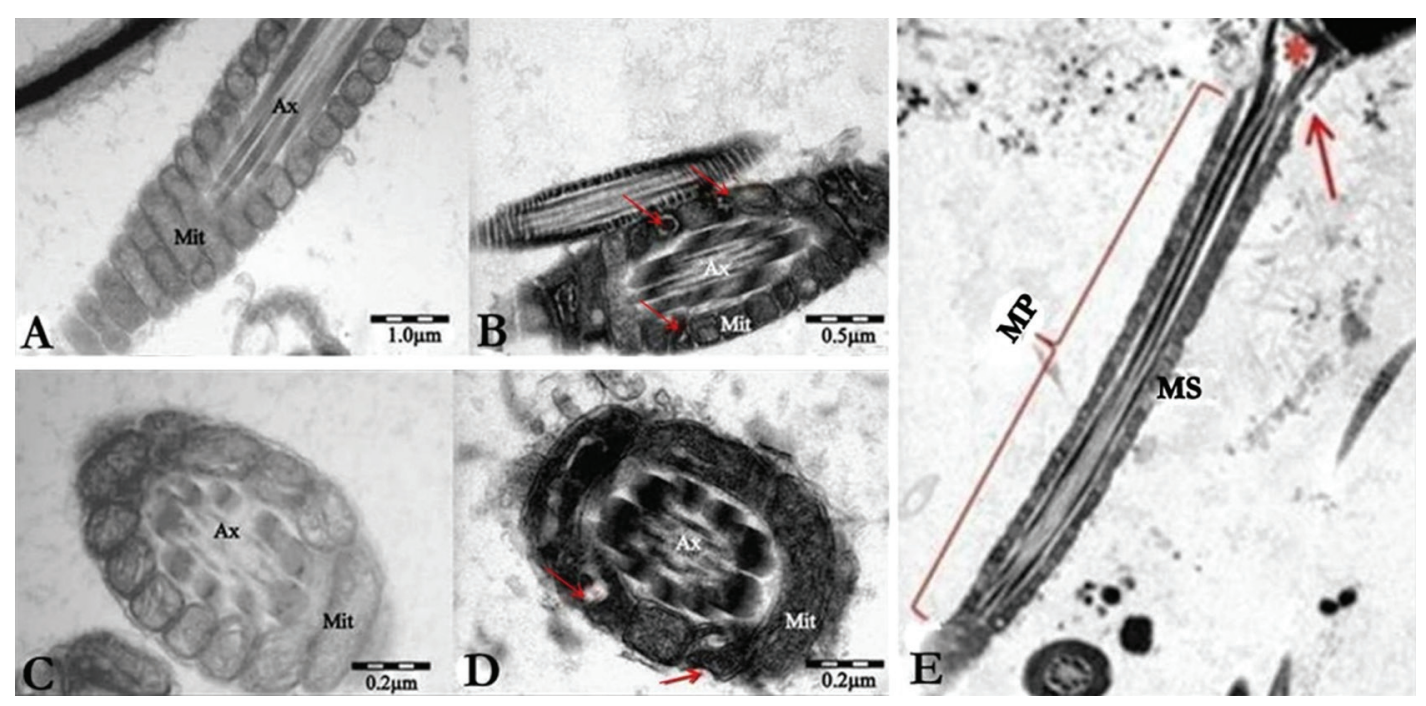

Fig.3. Electron microphotography of the sperm tail region obtained from fresh-diluted semen samples (control group) and frozen-thawed semen samples from six-banded armadillo (Euphractus sexcinctus). (A) Tangential/longitudinal section of the midpiece of the sperm showing normal mitochondria with ridges inserted in homogeneous matrix (control group). (B) Tangential/longitudinal section the midpiece of frozen-thawed sperm containing damaged mitochondria with heterogeneous matrix (arrows). (C) Cross section of the sperm midpiece, showing normal and well-defined mitochondria (control group). (D) Cross section of the sperm midpiece, showing cryoinjuries to mitochondria (arrows). (E) Mitochondrial sheath (MS) with a heterogeneous matrix along the whole midpiece (MP), and discontinuity of the membrane (arrow) in the neck region $\left(^{*}\right)$.

storage at $5^{\circ} \mathrm{C}$ for $18 \mathrm{~h}$. Such studies lead us to hypothesize that Xenatras would present a low resistance to the cold shock. In fact, some species present a high sensibility to the temperature reduction, which is proportional to the refrigeration rate, temperature range and temperature limit. Consequently, this phenomenon can induce a lethal stress in some cells, causng the rupture of plasma membrane with loss of spem cations and enzymes, thus irreversibly reducing its motility and metabolic activity (White 1993). On the other hand, the sperm from certain species are very resistant to thermal shock, because they typically present a stabilized plasma membrane containing a high cholesterol concentration (Kirk et al. 2001). Additionally, Parks \& Lynch (1992) hypotethize that some sperm can present a high resistance to rapid cooling, this being probably related to the glycolipid components of the sperm membrane. Concerning this matter, there are studies that correlate certain proteins and glycoproteins, present in bodily fluids, to the maintenance of cell viability at low temperatures (Bouvet \& Ben 2003, Davies et al. 2002). Therefore, it is likely that the vulnerability of gametes subjected to cold temperatures, found in certain species, like armadillos, is associated to low concentrations or absence of such specific substances. Although the molecular action mechanism of these components is not yet conclusive, we know that their effects on sperm preservation are directly proportional to their concentration in the media. Furthermore, the addition of penetrating cryoprotectants, like glycerol, can exacerbate the disequilibrium in sperm homeostasis previously caused by refrigeration (Holt 2000). Based on these statements, the present study evidences that cooling is a critical step for the armadillos' sperm during freezing protocols, which highlights the need for testing other buffering systems, cryoprotectants and equilibrium time.
Besides cooling, the freezing-thawing step provokes an even more significant reduction on armadillos' sperm quality, evidenced by very low post-thawing sperm motility (6\%). In fact, the main damages on cells usually occur during this step, which can provoke destabilization and even rupture of the membranes and loss of intracellular components, such as metabolic enzymes and ATP, with substantial loss of sperm viability (Bailey et al. 2003). However, the percentage of sperm that remained with viable (13\%) and functional $(24.7 \%)$ membranes after thawing was higher than that presenting some motility (6.1\%), suggesting that some armadillos' sperm could be live but immotile. This indicates that the motility does not necessarily reflect the sperm viability, a fact considered by Sa-Ardrit et al. (2006) who mentioned the non-occurrence of pregnancy in elephants artificially inseminated with thawed semen samples, even if those showed acceptable levels of sperm motility.

The plasma membrane is the primary site of injury in cryopreserved sperm (Parks \& Graham 1992); however, the increase in the proteins concentration of in the media can augment the stability of the sperm membrane, reducing the chances of alterations induced by refrigeration (DeLeeuw et al. 1990). Concerning this, the addition of egg yolk to the extender may have improved the resistance of the plasma membrane in some armadillos' sperm during the freezing-thawing step. The egg yolk's action derives from its low-density protein (LDL) that increases sperm resistance to thermal shock, and enhances the plasma membrane integrity (Moussa et al. 2002).

Although most semen cryopreservation protocols developed for mammals consider glycerol as a standard cryoprotectant (Watson 2000, Silva et al. 2003), its toxicity can promote osmotic changes that can affect the fluidity and 
the functional properties of plasma membranes during cooling, freezing and thawing (Holt 2000). This may be one of the reasons for the high incidence of post thawing non-viable sperm found for armadillo semen. However, we emphasize that this is only the first attempt of cryopreserving the armadillos semen, and the search for the appropriate concentration of an adequate cryoprotectant are still required, mainly considering that the ideal type and concentration of cryoprotectants for freezing sperm varies among species (Holt 2000).

Regarding the armadillos' sperm analysis at using fluorescent probes, we were unable to properly analyse the fresh sperm, because that the high viscosity of its seminal plasma do not allows the penetration of the fluorophores. In fact, an old study had yet revealed that armadillo sperm surface present some difficulties in incorporate fluorescent markers (Bedford \& Millar 1978). In this sense, a diluted sample was used as the control for the experiment, once extender promoted the reduction in medium viscosity and allowed the sperm rolleaux dissolution (Sousa et al. 2014), thus allowing the interaction among sperm membrane surface and fluorophores. This technique revealed that the mitochondria of the six-banded armadillo's sperm seems to be very sensible to the cryoinjuries, and this statement corroborates to the findings derived from the transmission electron microscopy. The mitochondrial dysfunction with reduction in ATP production may be responsible for decreased sperm motility, generally observed after thawing (Medeiros et al. 2002). At the same time, there are reports affirming that after the rupture of mitochondrial membranes, there is a release of pro-apoptotic factors (Ravagnan et al. 2002), which can cause irreparable structural and functional damage when moving to other sperm compartments (Martin et al. 2004). On the other hand, a few amout of armadillos' sperm presenting intact membranes even in the absence of mitochondrial activity was observed, which lead us to infer about the gradual effect of the pro-apoptotic factors after their release.

The main morphological alterations observed in six-banded armadillo semen are secondary defects, and in general, their proportions increase after the refrigeration step, certainly due to thermal shock and osmotic stress caused by cryopreservation procedures (Seager 1986). To prevent the formation of ice crystals, glycerol promotes the removal of intracellular water, and consequently, cell shrinkage and greater ion influx. During thawing, as a reverse effect, water inflow occurs, which may cause rupture of the membrane (Holt 2000) similarly to what was demonstrated in this study by ultrastructural image.

Abnormal shapes of the head of the six-banded armadillo sperm can also be attributed to the cryopreservation process due to damage to the cytoskeleton components, which are housed in the narrow spaces between the acrosome and the nucleus, and between the acrosome and the plasma membrane (Eddy \& O'Brien 1994). According to Watson's review (2000), there are some elements of the spermatic cytoskeleton, which are sensitive to temperature changes and can be depolymerized. Furthermore, we observed that acrosomal damage increased significantly during cooling and freezing. Nevertheless, we noted high percentages of sperm with an intact acrosome, similar to what was observed in canine semen (Peña et al. 1998). The acrosomal injuries of cryopreserved sperm observed in this experiment are characterized mainly by premature sperm capacitation. The F-actin depolymerization is one of the steps necessary to allow the approach between the plasma membrane and the outer acrosome membrane, promoting the acrosome exocytosis. This, perhaps, may be one explanation for the disorganized fusion of the membranes after refrigeration and cryopreservation of sperm (Watson 2000). This type of damage is probably derived from the occurrence of intracellular crystallization during the cryopreservation process. These are clearly identified by ultramicroscopy, but not always easily visible from observations with light microscopy. This fact may explain the low percentage of acrosomal abnormalities in thawed sperm samples from six-banded armadillos after the classic analysis of sperm morphology.

An interesting observation when analyzing the electronic ultramicrographies of armadillos' frozen-thawed sperm was the presence of damage on chromatin located adjacent to the acrosome, similarly as described for koalas. This kind of chromatin damage usually begins in the periacrossomal and basal regions of the sperm and subsequently expand to other regions of the nucleus during cryopreservation.

For domestic animals as equines (Thurston et al. 2002) and swines (Roca et al. 2006), whose studies on the evaluation of post-thawing sperm viability are intensely developed, one of the major limitations for the use of frozen semen is the individual variability to sperm freezeability. Similarly, a variable resistance to cryoinjuries was found among different armadillos used in present study. Therefore, it is pertinent to consider individual variation as an important characteristic for development of an appropriate protocol for semen cryopreservation in this species.

\section{CONCLUSIONS}

We described the initial attempt to cryopreserve the six-banded armadillos' (Euphractus sexcinctus) sperm.

Despite the fact that the results obtained in this study are consistent, we observed a high frequency of cryoinjuries in sperm, which could harm their fertilizing capability.

We highlight that this initial study is essential to improve the protocols for the cryopreservation of the six-banded armadillo's semen, because we monitored the response and behavior of the armadillos' sperm during the procedure, which allow us to identify critical points of the chilling-freezing-thawing process.

Additionally, the genetic material derived from the present assay is now available to the formation of germplasm banks, and could be gradually adapted for endangered armadillos' species as the three-banded (Tolypeutes sp.) and the giant ( $P$. maximus) armadillo.

As an audacious step, these cryopreserved samples could also be used in assisted techniques focused on studying the physiology of the oocyte-sperm cell interactions in this species. 
Acknowledgements.- We would like to thank professor Dr. Carlos Iberê A. Freitas for providing the animals used in the experiment; the Coordination for the Improvement of Higher Education Personnel (CAPES) for grants, and the Electron Microscopy Facility (Dept. Cell Biology and Developmental - ICB-USP) for techinal assistance.

\section{REFERENCES}

Amorim R.N.L., Emerenciano K.D.M., Sousa P.C., Castelo T.S., Lima G.L. \& Silva A.R. 2012. Short-term preservation at $5^{\circ} \mathrm{C}$ of Armadillo's (Euphractus sexcinctus) semen. Proc. III International Symposium Animal Biology of Reproduction (ISABR), Campinas/SP. 971p.

Amorim R.N.L., Sousa P.C., Castelo T.S., Santos E.A.A. \& Silva A.R. 2011. Características do sêmen de tatus-peba (Euphractus sexcinctus Linnaeus, 1758) coletados por eletroejaculação utilizando diferentes protocolos anestésicos. Proc. XVII Seminário de Iniciação Científica da UFERSA, Mossoró/RN. 47p.

Bailey J.L., Morrier A. \& Cormier N. 2003. Semen cryopreservation in farm species: an update. Can. J. Anim. Sci. 83:393-401.

Bedford J.M. \& Millar R.P. 1978. The character of sperm maturation in the epididymis of Ascrotal hyrax, Procavia capensis and Armadillo, Dasypus novemcinctus. Biol. Reprod. 19:396-406.

Bouvet V. \& Ben R.N. 2003. Antifreeze glycoproteins. Cell. Biochem. Biophys. 39:133-144.

Celeghini E.C., Arruda R.P., Andrade A.F., Nascimento J. \& Raphael C.F. 2007. Practical techniques for bovine sperm simultaneous fluorimetric assessment of plasma, acrosomal and mitochondrial membranes. Reprod. Domest. Anim. 42:479-488.

Crespilho A.M., Landim-Alvarenga F.C. \& Papa F.O. 2006. Infertilidade associada a defeito microtubular dos espermatozoides de jumento (Equus asinus) avaliados por microscopia eletrônica de transmissão. Ciência Rural 36:1507-1510.

Davies P.L., Baardsnes J., Kuiper M.J. \& Walker V.K. 2002. Structure and function of antifreeze proteins. Phil. Trans. R. Soc. Lond. B 357:927-935.

De Leeuw F.E., Chen H.C., Colenbrander B. \& Verkleij A.J. 1990. Cold-induced ultrastructural changes in bull and boar sperm plasma membranes. Cryobiology 27:171-183.

Eddy E.M. \& O’Brien D.A. 1994. The spermatozoon, p.29-77. In: Knobil E. \& Neil J.D. (Eds), The Fisiology of Reproduction. Raven Press, New York.

Heath E., Schaeffer N., Meritt Jr D.A. \& Jeyendran R.S. 1987. Rouleaux formation by spermatozoa in the naked-tail armadillo, Cabassous unicinctus. J. Reprod. Fertil. 79:153-158.

Hickman Jr C.P., Robertis L.S. \& Larson A. 2004. Princípios Integrados de Zoologia. Guanabara Koogan, Rio de Janeiro. 846p.

Hoe F.G.H., Sousa F.F., Rinca L. \& Lopes M.D. 2001. Efeito do diluidor sobre a viabilidade das células espermáticas caninas, mantidas a $37^{\circ} \mathrm{C}$. Revta Bras. Reprod. Anim. 25:466-468.

Holt W.V. 2000. Basic aspects of frozen storage of semen. Anim. Reprod. Sci. 62:2-33.

IUCN 2016. International Union for Conservation of Nature. IUCN Red List. Online Version. Available in <http://www.iucnredlist.org/search/details.php/8306/all> Access Jan. 5, 2016.

Karnovsky M.J. 1965. A formaldehyde-glutaraldehyde fixative of high osmolality for use in electron microscopy. J. Cell Biol. 27:137-138.

Kirk E.S., Graham J.K. \& Squires E.L. 2001. Increasing membrane cholesterol content benefits the motility of cooled equine semen. Proc. International Symposium on Stallion Reproduction, Fort Collins, 3:37.

Luba C.N., Boakari Y.L, Costa Lopes A.M., Silva Gomes M., Miranda F.R., Papa F.O. \& Ferreira J.C. 2015. Semen characteristics and refrigeration in free-ranging giant anteaters (Myrmecophaga tridactyla). Theriogenology $84: 1572-1580$.

Martin G., Sabido O., Durand P. \& Levy R. 2004. Cryopreservation induces an apoptosis-like mechanism in bull sperm. Biol. Reprod. 71:28-37.

Medeiros C.M.O., Forell F., Oliveira A.T.D. \& Rodrigues J.L. 2002. Current status of sperm cryopreservation: why isn't it better? Theriogenology 57:327-344.
Moussa M., Martinet V., Trimeche A., Tainturier D. \& Anton M. 2002. Low density lipoproteins extracted from hen egg yolk by an easy method: cryoprotective effect on frozen-thawed bull semen. Theriogenology 57:1695-1706.

Peña A.I., Barrio F., Quintela L.A. \& Herradón P.G. 1998. Effect of different glycerol treatments on frozen-thawed dog sperm longevity and acrossomal integrity. Theriogenology 50:163-174.

Parks J.E. \& Graham J.K. 1992. Effects of cryopreservation procedures on sperm membranes. Theriogenology 38:209-222.

Parks J.E. \& Lynch D.V. 1992. Lipid composition and thermotropic phase behavior of boar, bull, stallion, and rooster sperm membranes. Cryobiology 29:255-266.

Peres M.A., Benetti E.J., Milazzotto M.P., Visintin J.A., Miglino M.A. \& Assumpção M.E. 2008. Collection and evaluation of semen from the threetoed sloth (Bradypus tridactylus). Tissue Cell 40:325-331.

Pesch S. \& Bergmann M. 2006. Structure of mammalian spermatozoa in respect to viability, fertility and cryopreservation. Micron. 37:597-612.

Pukazhenthi B., Comizzoli P., Travis A.J. \& Wildt D.E. 2006. Applications of emerging technologies to the study and conservation of threatened and endangered species. Reprod. Fertil. Dev. 18:77-90.

Ravagnan L., Roumier T. \& Kroemer G. 2002. Mitochondria, the killer organelles and their weapons. J. Cell Physiol. 192:131-137.

Roca J., Hernández M., Carvajal G., Vázquez J.M. \& Martínez E.A. 2006. Factors influencing boar sperm cryosurvival. J. Anim. Sci. 84:2692-2699.

Sa-Ardrit M., Saikhun J., Thongtip N., Damyang M., Mahasawangkul S., Angkawanish T., Jansittiwate S., Faisaikarm T., Kitiyanant Y., Pavasuthipaisit K. \& Pinyopummin A. 2006. Ultrastructural alterations of frozen-thawed Asian elephant (Elephas maximus) spermatozoa. Int. J. Androl. 29:346352.

Santos E.A.A., Sousa P.C., Dias C.E.V., Castelo T.S., Peixoto G.C.X., Lima G.L., Ricarte A.R.F., Simão B.R., Freitas C.I.A. \& Silva A.R. 2011. Assessment of sperm survival and functional membrane integrity of the six-banded armadillo (Euphractus sexcinctus). Theriogenology 76:623-629.

Seager S.W.J. 1986. Artificial insemination in dogs, p.207-217. In: Burke T.J. (Ed.), Small Animal Reproduction and Infertility: a clinical approach to diagnosis and treatment. Lea and Febiger, Philadelphia.

Serafim M.K.B., Lira R.A., Costa L.L.M., Gadelha I.C.N., Freitas C.I.A. \& Silva A.R. 2010. Description of semen characteristics from six-banded armadillos (Euphractus sexcinctus) collected by electroejaculation. Anim. Reprod. Sci. 118:362-365.

Silva A.R., Cardoso R.C.S., Uchoa D.C. \& Silva L.D.M. 2003. Quality of canine semen submitted to single or fractionated glycerol addition during the freezing process. Theriogenology 59:821-829.

Silva A.R., Fontenele-Neto J.D., Cardoso R.C.S., Silva L.D.M., Chirinéa V.H. \& Lopes M.D. 2009. Description of ultrastructural damages in frozen-thawed canine spermatozoa. Ciênc. Anim. Bras. 10:595-601.

Silva M.A., Peixoto G.C., Castelo T.S., Lima G.L., Silva A.M., Oliveira M.F. \& Silva A.R. 2011. Recovery and cryopreservation of epididymal sperm from agouti (Dasiprocta aguti) using powdered coconut water (ACP-109c) and Tris extenders. Theriogenology 76:1084-1089.

Sousa P.C., Santos E.A.A., Bezerra J.A.B., Lima G. L., Castelo T.S., Fontenele-Neto J.D. \& Silva A.R. 2013. Morphology, morphometry and ultrastructure of captive six-banded armadillo (Euphractus sexcinctus) sperm. Anim. Repro. Sci. 140:279-285.

Sousa P.C., Santos E.A.A., Silva A.M., Castelo T.S., Peixoto G.C.X., Freitas C.I.A. \& Silva A.R. 2014. Viabilidade do sêmen de tatus-peba (Euphractus sexcinctus) centrifugado e diluído em Tris ou agua de coco em pó. Ciência Rural 44:1645-1650.

Thurston L.M., Siggins K., Mileham, A.J., Watson P.F. \& Holt W.V. 2002. Semen cryopreservation: a genetic explanation for species and individual variation? Cryo Letters 23:255-262.

Watson P.F. 2000. The causes of reduced fertility with cryopreserved semen. Anim. Reprod. Sci. 61:481-492.

White I.G. 1993. Lipids and calcium uptake of sperm in relation to cold shock and preservation: a review. Reprod. Fertil. Dev. 5:639-658. 